\title{
Optimal management of renal cell carcinoma in the elderly: a review
}

This article was published in the following Dove Press journal:

Clinical Interventions in Aging

18 April 2013

Number of times this article has been viewed

\author{
Amandine Quivy 1,2 \\ Amaury Daste' \\ Asma Harbaoui' \\ Sophie Duc ${ }^{2,4}$ \\ Jean-Christophe Bernhard ${ }^{2,3}$ \\ Marine Gross-Goupil' \\ Alain Ravaud ${ }^{1,2}$ \\ 'Department of Medical Oncology, \\ Hôpital Saint-André, Bordeaux \\ University Hospital, Bordeaux, \\ France; ${ }^{2}$ University of Bordeaux 2 \\ (Victor Ségalen), Bordeaux, France; \\ ${ }^{3}$ Department of Urology, Hôpital \\ Pellegrin, Bordeaux University \\ Hospital, Bordeaux, France; \\ ${ }^{4}$ Department of Geriatrics, Hôpital \\ Saint-André, Bordeaux University \\ Hospital, Bordeaux, France
}

Correspondence: Alain Ravaud

Department of Medical Oncology, Hôpital Saint-André, Bordeaux

University Hospital, Bordeaux, France

Tel +33556795808

Fax +33556795896

Email alain.ravaud@chu-bordeaux.fr
Abstract: Both the aging population and the incidence of renal cell carcinoma (RCC) are growing, making the question of tumor management in the elderly a real challenge. Doctors should be aware of the importance of assessing this specific subpopulation. An aggressive therapeutic approach may be balanced by the benefit of the treatment - care or cure - and the life expectancy and willingness of the patient. The treatment for local disease can be surgery (radical or partial nephrectomy) or ablative therapies (radiofrequency, cryotherapy). Even if in most cases surgery is safe, complications such as alteration of renal function may occur, especially in the elderly, with physiological renal impairment at baseline. More recently, another option has been developed as an alternative: active surveillance. In the past decade, new drugs have been approved in the metastatic setting. All the phase 3 trials have included patients without a limit on age. Nevertheless, data concerning the elderly are still poor and concern only a very selective subpopulation. The toxicity profile of targeted agents may interfere with pre-existent comorbidities. Furthermore, the metabolism of several agents via cytochrome P450 can cause drug interaction. The importance of quality of life is a major factor with regard to management of therapy. Finally, to date, there is no recommendation of systematic a priori dose reduction in the elderly. In this review we describe the various possibilities of treatment for localized RCC or metastatic RCC in an aging population.

Keywords: elderly, kidney cancer, renal cell carcinoma, surgery, targeted therapy, comorbidity

\section{Introduction}

Due to the increase in age of the population, the number of cancers in the elderly, including renal cell carcinoma (RCC), continues to grow. Major changes have occurred in the therapeutic management of kidney cancer in the past decade. RCC is the third most common urological cancer and accounts for $3 \%$ of all adult neoplasia. ${ }^{2}$ RCC consists of a heterogeneous group of tumors. The predominant subtype of malignant parenchymal tumors is clear cell carcinoma, accounting for $75 \%-85 \%$ of tumors. The remaining RCCs include papillary for approximately $15 \%$ and chromophobe subtype for $5 \% .^{2,3}$ The outcome is relatively poor, with about one-third with metastatic disease at diagnosis and approximately $50 \%$ of patients with localized disease relapsing. ${ }^{4}$

The standard curative treatment for localized diseases remains surgical excision with total nephrectomy. The benefit of this treatment is unclear for elderly people and particularly for frail people with a high risk of surgical complications. However, the development of new types of surgery with, for example, partial nephrectomy (PN) or laparoscopic surgery has modified the therapeutic approach to the localized tumor. 
At the same time, less aggressive and ablative techniques have been developed, such as radiofrequency or cryotherapy, and the question of active surveillance has also been tested. The multidisciplinary approach has enabled better assessment of the patient, especially the elderly, along with the risk assessment for each option, to define the safest and most effective treatment.

With regard to the metastatic setting of RCC, a real revolution has been reported, with the demonstration of efficacy of targeted agents such as sunitinib, sorafenib, everolimus, temsirolimus, bevacizumab, and, more recently, pazopanib and axitinib. ${ }^{5-11}$ The importance of the toxicity profile of all drugs and the notion of therapy management is especially of note in the subpopulation considered: those aged $>75$ years. These patients frequently have comorbidities requiring other medical agents, with an increased risk of drug interaction. Finally, these patients' wishes may be different, depending on their age, their symptoms, the prognosis, and the profile and intensity of the toxicity.

This review will report specific data on the management of elderly patients with RCC. Two settings of the disease will be considered: the local setting with, most of the time, a curative, therapeutic approach, and the metastatic setting, with a palliative, medical approach.

\section{Epidemiology}

Incidence worldwide is about 209,000 new cases per year and 102,000 deaths per year. In 2008, in Europe, 88,300 patients were diagnosed with RCC, and 39,230 died from the disease. ${ }^{12}$ The number of cases of RCC is increasing, with 57,760 patients diagnosed in 2009 in the US, of whom 12,980 died from RCC. ${ }^{13}$ This estimation is similar in the UK, with 19,300 new cases and 9500 deaths. ${ }^{12}$ From 2005 to 2009, the median age at diagnosis was 64 years. In general, $66.8 \%$ of the cases are diagnosed in the group of patients aged between 44 and 74 years, and $24.2 \%$ of RCC is diagnosed in patients who are aged $\geq 74$ years, with $18.4 \%$ for the $75-84$ year age group and $5.8 \%$ for those aged $>85$ years. ${ }^{14}$ Up to $30 \%$ of patients are metastatic at the time of diagnosis. Recurrence develops in approximately $40 \%$ of patients treated for a localized tumour. ${ }^{15-17}$ In the US, more than $80 \%$ of cancer patients aged $\geq 65$ years have at least one comorbidity ${ }^{18}$ requiring treatment, leaving them exposed to drug interactions.

\section{General assessment of the elderly}

The general assessment of the patient and the disease is of importance before choosing the therapeutic approach to be taken in both the local and metastatic settings.
Age-related physiological, cognitive, and social characteristics of elderly patients may influence management in this population. The usual health status assessment using the World Health Organization's performance status needs to be completed in this specific population. ${ }^{19}$ The Charlson et $\mathrm{al}^{20}$ classification enables the integration of the presence of comorbidities, which need to be recognized in order to estimate the risk of renal failure with surgery and the risk of drug interaction with targeted agents. ${ }^{20}$ Specific preoperative assessment using the American Society of Anesthesiologists score may help to predict the morbidity of surgery in the elderly. ${ }^{21}$

In practice, we can use the comprehensive geriatric assessment (CGA) in order to help us make therapeutic decisions. The CGA is a multidimensional, interdisciplinary diagnostic process to determine the medical, psychological, and functional capabilities of a frail elderly person in order to develop a coordinated and integrated plan for treatment and long-term follow-up. The objective of the CGA is to improve diagnostic accuracy and optimize medical treatment and health outcomes, thus improving function and quality of life. This evaluation includes comorbid conditions and disease severity, medication review, nutritional status, basic activities of daily living, instrumental activities of daily living (IADL), psychological assessment with mental status testing (Mini-Mental Status), and mood testing using the geriatric depression scale, social assessment, and environmental assessment. $^{22}$

With this evaluation we can consider that patients belong to three groups according to Balducci and Extermann: ${ }^{23}$ patients who can be treated like young patients, vulnerable patients, and frail patients.

Management should be individualized and take into consideration the life expectancy and the preferences of the patient. Assessment of prognosis is particularly important for individualizing care in the elderly population, and to do this we can use a prognostic score validated in elderly patients. Two scores can be used: the Lee prognostic index for 4-year mortality and the Carey prognostic index for 2-year mortality. The Lee prognostic index incorporates age, gender, self-reported comorbid conditions, and functional measures. Twelve independent predictors of mortality were identified: age, male gender, six comorbid conditions (diabetes, cancer, lung disease, heart failure, current tobacco use, and body mass index $<25$ ), and difficulty with four functional variables (bathing, walking several blocks, managing money, pushing large objects). ${ }^{24}$ The Carey index uses the same risk factors, such as activities of daily living, IADL, additional measures of physical function, age, and gender, without 
comorbidities, to predict 2-year mortality. ${ }^{25}$ The evidence from recent studies demonstrates that the domains evaluated in a CGA can predict morbidity and mortality in older patients with cancer. This is particularly true for IADLs and comorbidities, but more studies are needed to pinpoint screening strategies that might speed the integration of a geriatric assessment in an oncological setting. Efforts to address these research priorities are under way.

\section{Local treatment}

Due to the frequent use of imaging techniques, the incidence of renal tumors, notably asymptomatic and small $(<4 \mathrm{~cm})$, has increased in the last few decades ${ }^{26}$ particularly in elderly patients. Most of the renal tumors are RCC, and adequate treatment must be proposed. Nevertheless, some of them (about 20\%) are benign tumors, ${ }^{27}$ and aggressive treatment such as surgery is not acceptable, especially for elderly people with a risk of renal failure. Biopsy has traditionally been reserved for complex cases to confirm benign or malignant lesions. With new techniques, percutaneous biopsy appears to be safe, providing more tissue, with a minimal risk of tumor spread, even in small renal masses. ${ }^{28,29}$ Because small renal masses are increasingly diagnosed in older people, an accurate diagnostic with biopsy may lead to a change in treatment, and must be recommended for elderly people, particularly in case of small renal masses. Depending on tumor location, kidney function, or contralateral kidney and comorbidity, different therapeutic approaches can be proposed for localized RCC in an elderly population, taking into consideration the efficacy (local, oncologic control)/risk ratio (morbidity and mortality).

For localized malignant tumors, nephrectomy remains the standard treatment. PN may be proposed depending on the size and location of the tumor. ${ }^{30}$ Recently, focalized treatment, such as radiofrequency or cryotherapy, has been developed and may be considered as an option, especially in frail patients. Tumor size is important, and all types of treatment can be discussed for small renal masses ${ }^{31}$ (Table 1), which is not the case for bigger tumors.

\section{Surgery}

Historically, the curative treatment for localized RCC was radical nephrectomy (RN). Surgical techniques have decreased complications, notably with the introduction of laparoscopic procedures that decrease blood loss, transfusion rate, pain, and hospital stays. ${ }^{32,33}$ For some authors, laparoscopic techniques are interesting in elderly populations, because they do not increase the rate of complications. In a large series of patients aged at least 75 years, Guzzo et $\mathrm{al}^{34}$ reported a $22.6 \%$ complication rate overall and $13.7 \%$ in patients aged $>80$ years.

More recently, PN can be proposed for solitary, small RCCs $(<4 \mathrm{~cm}-\mathrm{T} 1 \mathrm{a}),{ }^{30}$ especially in patients presenting with a single kidney or alteration of kidney function. The prognosis for surgical resection of small renal tumors is good, with a 5-year cancer-specific survival rate of $97 \%$ and $87 \%$ for T1a and $\mathrm{T} 1 \mathrm{~b}$, respectively. This rate decreased to $71 \%$ with stage $\mathrm{T} 2$ according to the 2002 American Joint Committee on Cancer. ${ }^{35}$ Elderly patients who in many cases present with alterations of the renal function with decreased glomerular filtration rate, associated with increased mortality and hospitalization, ${ }^{36}$ are good candidates for this type of surgery. Several studies comparing PN and RN have been reported, most of which reported the safety of the partial resection in terms of overall survival (OS) rates $^{37}$ and rate of local or distance recurrence..$^{38,39}$

In terms of complication rates and mortality, both techniques are almost identical, except for perioperative bleeding $(P<0.001)$ and urinary fistulas $(P<0.001)$, which are more frequent in partial surgery. ${ }^{40}$ One major advantage of

Table I Indications and contraindications of treatment options for small renal masses ${ }^{31}$

\begin{tabular}{|c|c|c|}
\hline Treatment & Indications & Contraindications \\
\hline Partial nephrectomy & $\begin{array}{l}\text { Enhancing solid or complex cystic renal mass } \\
\text { whenever technically feasible } \\
\text { Fit patients with limited medical comorbidity } \\
\text { Hilar tumors (contraindication to ablative treatment) }\end{array}$ & $\begin{array}{l}\text { Severe and irreversible coagulopathy } \\
\text { Abdominal scars (relative contraindication) }\end{array}$ \\
\hline Ablative therapy & $\begin{array}{l}\text { Renal masses }<3 \mathrm{~cm} \\
\text { Elderly patients or patients with medical comorbidities } \\
\text { and high surgical risk who desire active treatment } \\
\text { Patients with solitary kidneys and baseline renal dysfunction } \\
\text { Informed younger patients who refuse surgery } \\
\text { Renal masses in a postsurgical renal remnant }\end{array}$ & $\begin{array}{l}\text { Healthy young patients } \\
\text { Severe and irreversible coagulopathy } \\
\text { Hilar tumors close to proximal ureter and } \\
\text { central collecting system } \\
\text { Tumors with irregular shape and infiltrative appearance } \\
\text { Unwillingness to comply with a strict follow-up }\end{array}$ \\
\hline Active surveillance & $\begin{array}{l}\text { Patient with limited life expectancy } \\
\text { Severe renal dysfunction }\end{array}$ & Unwillingness to comply with a strict follow-up \\
\hline
\end{tabular}


partial surgery is nephron-sparing, with a lower increase of creatininemia in the partial surgery group $(P<0.0001){ }^{40}$ In some studies, the rate of renal failure was significantly higher in the RN group compared with the partial group (22.4\% vs $11.6 \%$ at 10 years) and was associated with more significant chronic renal impairment. ${ }^{41}$ In 89 patients with PN, La Rochelle et $\mathrm{al}^{42}$ reported that cold ischemia time and the presence of three vascular risk factors (diabetes, hypertension, and cardiovascular disease) were the only factors significantly associated with the decrease of glomerular filtration rate in the postoperative period. Fewer data have been reported with regard to quality of life but seem to be in favor of partial surgery. ${ }^{43}$

Few studies have focused specifically on surgery in the elderly. In a retrospective study from 1988 to 2005, and using the Surveillance, Epidemiology and End Results database, Hellenthal et $\mathrm{al}^{44}$ identified 59,944 patients treated for RCC with surgery, of whom 4587 patients were aged $\geq 80$ years. Interestingly, in this study, the RCC-related death rate was similar in both younger and older patients (15\% vs $17 \%$, respectively), whereas older patients were approximately 2.3 times more likely to die from all causes except RCC than younger patients, confirming their frail nature. Elderly patients treated by $\mathrm{RN}$ were 1.31 times more likely to die overall $(P=0.004)$ and 2.54 times more likely to die of RCC than people of the same age treated by PN $(P<0.001)$. In a retrospective, monocentric study between 1993 and 2003, mortality and morbidity were analyzed for 1023 patients treated for localized RCC according to their age. A total of 908 patients were aged $<75$ years, and 115 were aged 75-88 years. Preoperative mortality was higher in older patients $(1.7 \%)$ than in younger patients $(0.3 \%)$, but the difference was not significant $(P=0.29)$. The overall postoperative morbidity and mortality was correlated with increased American Society of Anesthesiologists score ( $P=0.005$ and $P=0.008$, respectively) but not with age. ${ }^{45}$ Surgical complications in elderly patients are low, proved by a retrospective study of 117 elderly people who underwent surgical resections between 2004 and 2007. For every type of surgery, complication rates were very low in each group at $12 \%$ and $15 \%$ for RN and PN, respectively, and the only major complications were bleeding. ${ }^{46}$ According to Roos et al, ${ }^{47}$ renal function in the elderly who had undergone renal surgery was preserved with each technique, and the increase in serum creatinine was low before surgery and after treatment was $1 \mathrm{mg} / \mathrm{dL}$ and $1.4 \mathrm{mg} / \mathrm{dL}(P=0.004)$, respectively, for radical surgery and $1.1 \mathrm{mg} / \mathrm{dL}$ and $1.2 \mathrm{mg} / \mathrm{dL}(P=0.569)$ for PN.

\section{Ablative therapies}

Other methods have recently been developed, such as ablative therapy (AT), including cryoablation or radiofrequency ablation (RFA), and may be of interest in treating local disease in the elderly. These two methods can be performed using different approaches, the laparoscopic approach requiring general anesthesia or the percutaneous approach, which can be performed under local anesthesia. ${ }^{48}$ This option enables treatment for frail patients such as the elderly with, in some cohorts, the possibility of effective ambulatory treatment. ${ }^{49}$ Clinical outcomes with these treatments are relatively the same as for surgery. For example, in one study with 84 tumors ablated and a long follow-up of more than 3 years, Tracy et $\mathrm{al}^{50}$ described a 5-year recurrence-free survival rate and a metastasis-free survival rate of $93 \%$ and $95 \%$, respectively. In a meta-analysis of 47 series including 1375 renal tumors, Kunkle and $\mathrm{Uzzo}^{48}$ reported a local tumor progression of $5.2 \%$ and $12.9 \%$ with cryoablation or RFA, respectively $(P<0.0001)$. Progression to metastatic disease was low in both groups, with $1 \%$ and $2.5 \%$ in the cryoablation and RFA groups, respectively $(P=0.06)$. In the case of the absence of local control, notably with local recurrence or incomplete treatment, repeat ablation provided durable outcomes. ${ }^{50} \mathrm{Using}$ the Surveillance, Epidemiology and End Results database, Choueiri et $\mathrm{al}^{51}$ analyzed subjects treated for T1N0M0 RCC between 2004 and 2007 by thermal ablation or surgery. After a median follow-up of 21.2 months, there was no difference in cancer-specific survival at 2 years in multivariate analysis, with cancer-specific survival rates at 2 years of $98 \%, 99.3 \%$, and $98 \%$ for AT, PN, and RN, respectively ( $P=0.2$ for thermal ablation vs PN). A meta-analysis comparing specifically laparoscopic cryoablation (LCA) versus $\mathrm{PN}$ in 6642 patients $^{52}$ described rates of local tumor progression of $8.5 \%$ and $1.9 \%$ for LCA and PN, respectively $(P<0.001)$. Interestingly, a low rate of distant metastases was described, with $1.8 \%$ and $1.9 \%$ for LCA and PN, respectively (difference not statistically significant, $P=0.126$ ).

With regard to complications of ablative techniques, the rates are between $4 \%$ and $37 \%$, and most of them are bleeding, pain (usually temporary), pneumothorax, or thermal lesion of the digestive tract, or lesion of the urinary tract. ${ }^{53}$ For Klatte et al, ${ }^{52}$ incidence of perioperative complications was increased with PN compared with LCA, with $23.5 \%$ and $17 \%$, respectively $(P<0.001)$, and more important major complications occurred more frequently following PN compared with LCA (19.2\% vs 10.2\%). These complications are more important with increased tumor size, as reported by Schmit et al ${ }^{54}$ in 115 patients treated with percutaneous 
cryoablation for RCC. Preservation of renal function seems to be an important goal in AT, even though the data are limited.

Finally, even if there has been no specific study in the elderly population, this option has been frequently proposed to older patients. For example, half of the population treated by AT in the study reported by Choueiri et $\mathrm{al}^{51}$ were aged $\geq 70$ years.

\section{Active surveillance}

Given that the tumor size growing rate of small RCC is low and that the capacity to induce dissemination of metastases is limited, active surveillance can be proposed in an asymptomatic setting. ${ }^{55,56}$ Most of the active surveillance series are small, retrospective, with short-term follow-up, and have been carried out in single institutions. In a meta-analysis of the major studies of observed renal masses, ${ }^{57}$ the average growth rate was $0.28 \mathrm{~cm}$ per year $(0.009-0.86 \mathrm{~cm})$. About $1 \%$ of patients developed metastases during the observation period. In most of the cases, histological subtypes and nuclear grade can be defined and thus enable an adaptation of the rhythm of active surveillance. Even in a biopsy that takes only a small amount of tumor, it appears that concordance between biopsy and surgical specimens is relatively important. ${ }^{28,58}$ For small tumors (T1a and some T1b) in the frail, such as some elderly patients, active surveillance after biopsy can be an interesting option. Beisland et $\mathrm{al}^{59}$ reported the cases of 63 elderly patients with principally $\mathrm{T} 1$ tumors treated by observation where the 5-year OS rates and cancerspecific survival rates were $42.8 \%$ and $93.3 \%$, respectively. The cancer-specific survival was significantly better in tumors $<4 \mathrm{~cm}$ compared with those $>4 \mathrm{~cm}(P=0.032)$. This study reported that elderly patients with small renal masses die from causes other than renal cancer, the most common being cardiovascular. Active surveillance, the least invasive strategy, may be a reasonable option for elderly people. ${ }^{60}$ Patients should be reassured that if progression occurs, a delayed operation can be proposed, with the same outcome as for an immediate intervention.

In summary, for localized treatment in terms of cancer control, each type of surgery (PN or RN) has the same outcome. For small renal masses, AT has the same efficacy as surgery with fewer complications, but when the tumor size is increasing ( $>1.5 \mathrm{~cm}$ and clearly at $20-30 \mathrm{~mm}$ ) cancer control is less important. In terms of complications, each technique is relatively acceptable in elderly populations, even though some differences have been proven. Whenever possible, we need to choose the technique with the least impact on quality of life in accordance with the patient's comorbidities. Due to the low growth of small renal masses, active surveillance is a good alternative in frail, elderly people.

\section{General treatment}

$\mathrm{RCC}$ is resistant to chemotherapy, and for many years the treatment for metastatic disease was interferon (IFN)- $\alpha$ and interleukin-2. Considering that the response rate with cytokines was very low (5\%-20\%), the median OS not exceeding one year and then on other hand the toxicity was usually severe, in particular when elderly patients were treated, cytokines were not usually used in elderly patients. ${ }^{61}$ Therapy has changed in metastatic settings with the arrival of targeted agents, with two types of drugs: the antiangiogenic agents and the mammalian target of rapamycin inhibitors. The first class of agents includes bevacizumab, a monoclonal antibody targeting the vascular endothelial growth factor, administered by infusion, and the vascular endothelial growth factor receptor tyrosine kinase inhibitors (TKIs) sunitinib, sorafenib, pazopanib, and axitinib, orally administered. These new drugs were assessed without age limitation, and all studies have included patients aged $\geq 80$ years. ${ }^{62}$ Nevertheless, several limitations should be acknowledged: the relatively small cut-off value of young versus old patients (65 years), patients aged $>75$ years were under-represented, and the selection of patients according to other inclusion and exclusion criteria, especially comorbidities, may make the results inadequately safe. Considering both the potential toxic effects and the fragility of the elderly population, physicians may have hesitated in including this subpopulation in a clinical trial. ${ }^{63}$

Furthermore, these agents induced frequent side effects in the overall population, including sometimes severe adverse events, justifying a dose reduction and even treatment interruption. The toxicity profile may be different according to the class of agent considered, and may help in choosing the agent, in respect of the indication. Bevacizumab appears easier to manage, with hypertension being the major frequent side effect. Nevertheless, the adjunction of IFN can be limiting due to the well-known toxicity profile of this agent. The frequent second effects of TKIs are hypertension, cardiovascular disorders, skin toxicity, hand and foot syndrome, and gastrointestinal disorders. ${ }^{5,6,65,67}$ Moreover, asthenia and anorexia, being more difficult to evaluate and to control, can be a specific point to consider for the elderly. The more frequent adverse effects of mammalian target of rapamycin inhibitors, everolimus and temsirolimus, include stomatitis, rash, fatigue, diarrhea and pneumonitis, and metabolic disorders such as diabetes, hypertriglyceridemia, and hypercholesterolemia. ${ }^{7,8}$ 
Some of these disorders may pre-exist in an elderly population and usually need to be treated. In the US, more than $80 \%$ of cancer patients aged $>65$ years have at least one comorbidity. ${ }^{61}$ Nearly two-thirds of elderly patients with RCC (aged $\geq 75$ years) concurrently suffer from conditions such as cardiovascular disease or diabetes. ${ }^{62,63}$ Moreover, because of these comorbidities, elderly patients may already be treated, thus exposing them to drug interactions, especially with the TKI family, eliminated via the CYP 450, exposing patients to a risk of increased toxicity or decreased efficacy (Table 2). Finally, the patients' preferences may differ depending on their age and quality of life.

For elderly patients, maintaining disease control is an important goal of treatment. Because of these characteristics, geriatric evaluation is a major component of the individualization of treatment. It is very important to prevent side effects by prophylactic treatments, to educate these patients, and to regularly monitor the emergence of adverse effects, clinical response, and quality of life. One major aspect of toxicity in older patients is the severity of consequences and the lack of reactivity in controlling them. The main example is diarrhea, with major risk of dehydration and renal failure in patients with less perception of being thirsty. The risk of stomatitis, with difficulties in swallowing and eating and with loss of weight induced by less food intake, may be of note in elderly patients. Finally, skin toxicity with functional effect can also be a specific concern in the specified subpopulation.

In this article we report specific data on elderly populations in the main studies that have validated each treatment for metastatic RCC, with the median age and the oldest age of the patients of the experimental arm (Tables 3,4).

Table 2 Major drugs suspected of potential drug interaction with targeted agents

\begin{tabular}{lll}
\hline $\begin{array}{l}\text { Cytochromes } \\
\text { P450 }\end{array}$ & Inhibitors & Inducers \\
\hline CYP IA2 & Enoxacine, fluvoxamine & Alcohol, tobacco, \\
CYP 2C8 & Gemfibrozil & St John's wort \\
CYP 2D6 & Fluoxetine, paroxetine, & (Hypericum \\
& quinidine, thionidazine & perforatum), \\
CYP 3A4 & Grapefruit juice, amiodarone, & carbamazepine, \\
& diltiazem, verapamil, & phenobarbital, \\
& ketoconazole, itraconazole, & phenytoine, \\
& voriconazole, posaconazole, & rifampycine, \\
& fluconazole, miconazole, & rifabutine, \\
& ritonavir, nelfinavir, amprenavir, & efavirenz, \\
& indinavir, atazanavir, & nevirapine, \\
& erythromycine, clarithromycine, & griseofulvine \\
& josamycine, telithromycine & \\
\hline
\end{tabular}

Abbreviation: CYP, cytochrome P450.
In these trials, few details about the elderly population have been reported (except for sorafenib), and most of the data have been reported in conference abstracts. In the following paragraphs we consider each drug used in metastatic RCC: sunitinib, sorafenib, bevacizumab, temsirolimus, everolimus, and pazopanib.

In the phase 3 trial of sunitinib, the results show that the median progression-free survival (PFS) was longer (11 months vs 9 months), the objective response rate was better (31\% vs $6 \%)$, and the quality of life was better in the sunitinib group. This efficacy was similar in all subgroups of patients and particularly the same for patients aged $<65$ years and $\geq 65$ years. $^{5}$ At the 2011 American Society of Clinical Oncology meeting, the authors reported a retrospective analysis of efficacy and safety of sunitinib from six clinical trials in patients aged $<70$ years versus $\geq 70$ years with metastatic RCC. The efficacy (median PFS and median OS) was similar in both groups. Some adverse events were significantly less common in patients aged $<70$ years versus $\geq 70$ years, including fatigue ( $59 \%$ vs $69 \%$ ), decreased appetite and loss of weight (29\% vs 53\%), cough (20\% vs $29 \%$ ), peripheral edema (17\% vs $27 \%$ ), anemia (17\% vs $25 \%$ ), and thrombocytopenia ( $16 \%$ vs $25 \%$; all $P<0.05){ }^{64}$ At the 2012 Genitourinary Cancers American Society of Clinical Oncology Symposium, the authors evaluated toxicity and dose reductions in patients aged $\geq 70$ years with metastatic RCC. ${ }^{65}$ They found $65 \%$ of toxicities grade $3-4$ and dose reductions for $64 \%$ of patients with the standard treatment (sunitinib $50 \mathrm{mg} / \mathrm{d}$, 4 week on/2 week off) and $42 \%$ of toxicities grade 3-4 and dose reduction for $40 \%$ of patients with adapted treatment $(37.5 \mathrm{mg} / \mathrm{d}, 4$ week on/2 week off or $25 \mathrm{mg} / \mathrm{d}, 4$ week on/2 week off or $37.5 \mathrm{mg} / \mathrm{d}$ continuous).

Table 3 Algorithm for systemic treatment in metastatic renal cell carcinoma ${ }^{30}$

\begin{tabular}{|c|c|c|c|}
\hline $\begin{array}{l}\text { Histology } \\
\text { and setting }\end{array}$ & Risk group & Standard & Option \\
\hline $\begin{array}{l}\text { Clear cell } \\
\text { first line }\end{array}$ & $\begin{array}{l}\text { Good or } \\
\text { intermediate } \\
\text { Poor prognosis }\end{array}$ & $\begin{array}{l}\text { Sunitinib, bevacizumab } \\
\text { ( } \pm \text { IFN), pazopanib } \\
\text { Temsirolimus }\end{array}$ & $\begin{array}{l}\text { Cytokines, } \\
\text { sorafenib } \\
\text { Sunitinib, } \\
\text { sorafenib }\end{array}$ \\
\hline \multirow[t]{2}{*}{$\begin{array}{l}\text { Clear cell } \\
\text { second line }\end{array}$} & Post cytokines & $\begin{array}{l}\text { Sorafenib, pazopanib, } \\
\text { axitinib }\end{array}$ & Sunitinib \\
\hline & Post TKI & Everolimus, axitinib & Sorafenib \\
\hline $\begin{array}{l}\text { Clear cell } \\
\text { third line }\end{array}$ & Post two TKIs & Everolimus & \\
\hline $\begin{array}{l}\text { Non clear } \\
\text { cell histology }\end{array}$ & & & $\begin{array}{l}\text { Temsirolimus, } \\
\text { sunitinib, } \\
\text { sorafenib }\end{array}$ \\
\hline
\end{tabular}

Abbreviations: IFN, interferon; TKI, tyrosine kinase inhibitor. 
The median PFS and the median OS were not different in the adapted and standard schedules. The authors concluded that an adapted schedule does not appear to influence the efficacy of treatment. ${ }^{65}$ However, we think that dose reductions in the elderly population may influence the efficacy of treatment, because there is a relationship between drug pharmacokinetics and response rate. ${ }^{66}$

In the phase 3 trial on sorafenib, the median PFS was 5.5 months in the sorafenib group and 2.8 months in the placebo group $(P<0.001)$. The benefit was the same for patients aged $<65$ years and for patients aged $\geq 65$ years. ${ }^{6}$ A retrospective subgroup analysis of data from this trial examined the safety and efficacy of sorafenib in older (aged $\geq 70$ years) and younger patients (aged $<70$ years). Median PFS and clinical benefit rates (complete response plus partial response plus stable disease) were similar in younger and older sorafenib-treated patients. Among older patients, sorafenib delayed the time to deterioration of health status. With regard to adverse events, the incidence was higher in elderly patients receiving sorafenib $(98.6 \%$ vs $94.2 \%$ ), and there were more grade 3 toxic effects in older sorafenib-treated patients than in younger sorafenibtreated patients (40\% vs 29.4\%). The most frequently reported adverse events among the older group were rash or desquamation, diarrhea, alopecia, fatigue, hand-foot skin reaction, and anorexia. The difference between older and younger patients was statistically significant for rash desquamation and diarrhea. Approximately half of the adverse events among both younger and older sorafenibtreated patients were grade 1 and 2 and were medically manageable. ${ }^{67}$
For the other agents, bevacizumab, pazopanib, temsirolimus, and everolimus, only data regarding efficacy in elderly patients have been reported, but not safety.

In the phase 3 trial of bevacizumab, the median PFS was significantly longer in the bevacizumab plus IFN- $\alpha$ group than in the control group: 10.2 months versus 5.4 months $(P=0.0001)$. These results are statistically significant for patients aged between 40 years and 64 years but not for the group of patients aged $>65$ years. ${ }^{9}$ The difficulty of using cytokines for elderly patients is well established; nevertheless, it has been reported that the efficacy still remains, even with a decreased dosage of cytokines, so bevacizumab seems to be a good drug for elderly patients. ${ }^{68}$

In the phase 3 trial of pazopanib, the median PFS was better in the pazopanib group: 9.2 months versus 4.2 months $(P<0.0001)$, and there was a benefit both for patients aged $<65$ years and for patients aged $\geq 65$ years. ${ }^{10}$ Pazopanib has the same profile of tolerance as the other TKIs.

In the phase 3 trial testing temsirolimus, OS was better in the temsirolimus group for patients aged $<65$ years but not for patients aged $\geq 65$ years. $^{8}$

For everolimus, there was a better PFS in the everolimus group for patients aged $<65$ years and for those aged $\geq 65$ years. $^{7}$

It is therefore of note that treatment for metastatic RCC can be used in elderly patients, and these results show efficacy for this population. Nevertheless, these treatments may be more toxic for elderly patients, because of comorbidities, drug interactions, and health status. The adverse events seem to be manageable with prophylactic treatment, patient education, and monitoring of response, toxicity, and quality of life.

Table 4 Summary of the phase III trials for approved agents with median age and oldest patient

\begin{tabular}{|c|c|c|c|c|c|c|}
\hline Phase 3 trial & $\begin{array}{l}\text { Median age } \\
\text { (years) }\end{array}$ & $\begin{array}{l}\text { Age of oldest } \\
\text { patient (years) }\end{array}$ & $\begin{array}{l}\text { Clinical } \\
\text { benefit }^{\mathrm{a}}\end{array}$ & $\begin{array}{l}\text { PFS } \\
\text { (months) }\end{array}$ & $\begin{array}{l}\text { OS } \\
\text { (months) }\end{array}$ & Toxicity \\
\hline Sutent ${ }^{66}$ & 62 & 87 & $39.5 \%$ & II & & $\begin{array}{l}\text { Diarrhea, vomiting, hypertension, hand-foot } \\
\text { syndrome, neutropenia, anemia, thrombocytopenia, } \\
\text { cough, peripheral edema, fatigue, anorexia }\end{array}$ \\
\hline Sorafenib ${ }^{67}$ & 58 & 86 & $57 \%$ & 5.5 & 19.3 & $\begin{array}{l}\text { Diarrhea, fatigue, rash, hand-foot syndrome, } \\
\text { anorexia, anemia, hypertension }\end{array}$ \\
\hline $\begin{array}{l}\text { Bevacizumab + } \\
\text { IFN- } \alpha^{9}\end{array}$ & 61 & 82 & $38.5 \%$ & 10.2 & & Bleeding, hypertension, proteinuria \\
\hline Pazopanib ${ }^{10}$ & 59 & 85 & $68.3 \%$ & 9.2 & & $\begin{array}{l}\text { Diarrhea, vomiting, hypertension, hair color } \\
\text { changes, nausea, anorexia, arterial thrombotic } \\
\text { events, hemorrhagic events, ALT and AST elevation }\end{array}$ \\
\hline Temsirolimus $^{8}$ & 58 & 81 & $32.1 \%$ & 3.8 & 10.9 & $\begin{array}{l}\text { Rash, peripheral edema, stomatitis, } \\
\text { nausea, hyperglycemia, hyperlipidemia, } \\
\text { hypercholesterolemia, diarrhea, anemia, dyspnea }\end{array}$ \\
\hline Everolimus $^{7}$ & 61 & 85 & $64 \%$ & 4 & & Stomatitis, rash, fatigue, pneumonitis, diarrhea \\
\hline
\end{tabular}

Note: ${ }^{a}$ Clinical benefit $=$ complete response + partial response + stable disease.

Abbreviations: ALT, alanine aminotransferase; AST, aspartate aminotransferase; IFN, interferon; OS, overall survival; PFS, progression-free survival. 
Table 5 Specific considerations for the elderly at each stage of patient treatment

\begin{tabular}{|c|c|}
\hline Patient selection & $\begin{array}{l}\text { - Consider the following in the decision to start treatment: } \\
\text { - Physiological age } \\
\text { - Comorbidities } \\
\text { - Drug toxicity profile }\end{array}$ \\
\hline Before treatment & $\begin{array}{l}\text { - Determine the patient's goals for therapy } \\
\text { - Advise the patient to resolve pre-existing health conditions, such as hypertension, skin disorders, and foot problems } \\
\text { - Take a full inventory of the medications and dietary supplements the patient is taking } \\
\text { - Inquire about the patient's support system } \\
\text { - Arrange regular nurse outreach, if necessary } \\
\text { - Educate the patient on drug dosing and administration, and recognition and management of adverse effects }\end{array}$ \\
\hline During treatment & $\begin{array}{l}\text { Monitor for: } \\
\text { - Emergence of adverse effects } \\
\text { - Understand that some adverse effects may affect elderly patients differently than they would younger patients } \\
\text { - Arrange regular nurse outreach, if necessary } \\
\text { - Be prepared to act quickly and aggressively if adverse effects emerge } \\
\text { - Consider dose modifications, if necessary } \\
\text { - Quality of life } \\
\text { - Regularly inquire about the impact of adverse effects on activity levels } \\
\text { - Potential drug-drug interactions } \\
\text { - Regularly inquire about any new medications the patient may be taking } \\
\text { - Clinical response to treatment } \\
\text { - Regularly perform imaging scans to monitor disease state }\end{array}$ \\
\hline
\end{tabular}

Adapted from Dutcher et al. ${ }^{69}$

The recommendations made by Dutcher et $\mathrm{al}^{69}$ for sorafenib can be extended to all treatments proposed for metastatic RCC in elderly patients in order to obtain disease control and to maintain a good quality of life (Table 5).

\section{Conclusion}

In summary, the management of an elderly population with RCC needs precise assessments of the disease (stage, prognosis) and of the patient (median life expectancy, fragility, performance status, comorbidity, treatments, willingness). In the local setting, surgery still remains a good option in selected elderly patients, with different techniques, such as PN or laparoscopic surgery. Other less invasive therapies, such as RFA, cryotherapy, or high-intensity focused ultrasound, may be very interesting alternatives, depending on the size and location of the tumor, and, most of the time, limit the deterioration of renal function. Finally, active surveillance may also be a good alternative for small tumors after biopsy specifying the histology and aggressivity (Fürhman Grade).

Targeted agents have demonstrated similar efficacy in both older patients and younger patients. No limitation of age was considered in the major phase 3 trials testing each drug. Unfortunately, only one study on sorafenib has specifically considered the older subset. ${ }^{65}$ The safety of the agents, considering the specific subpopulation with potential drug interaction, may be difficult to manage at the start of treatment. The severity and the consequences of adverse effects such as diarrhea or mucosal inflammation may be lifethreatening, thus justifying the assessment of the patient and his or her resources, prophylactic management, and patient education in case of an adverse event. If these points are followed, there is no need for systematic drug reduction in the elderly. Nevertheless, dose escalation in selected patients may be of interest with a reduced first dose intake. The possibility of controlling the exposure of the patient to the agent by pharmacokinetics may be an interesting tool, though is not performed routinely. Apart from the fit patient with a metastatic setting of RCC who can be treated in the same way as younger patients, there is clearly a need for prospective assessment for very elderly patients, ie, those aged $\geq 80$ years, and for patients considered to be vulnerable or frail on geriatric scales.

Finally, the international recommendations have to be followed. In first-line treatment of clear cell carcinoma, the results of the PISCES (Patient Preference Study of Pazopanib Versus Sunitinib in Advanced or Metastatic Kidney Cancer) trial, in favor of pazopanib in terms of safety, when associated with the results of the COMPARZ (Pazopanib Versus Sunitinib in the Treatment of Locally Advanced and/or Metastatic Renal Cell Carcinoma) trial, with noninferiority between pazopanib and sunitinib, may argue for the choice of pazopanib, if available and depending on the country, in the elderly. ${ }^{70,71}$ 


\section{Disclosure}

The authors report no conflicts of interest in this work.

\section{References}

1. Martin JE, Sheaff MT. The pathology of ageing: concepts and mechanisms. J Pathol. 2007;211(2):111-113.

2. Cohen HT, McGovern FJ. Renal-cell carcinoma. $N$ Engl J Med. 2005;353(23):2477-2490.

3. Kovacs G, Akhtar M, Beckwith BJ, et al. The Heidelberg classification of renal cell tumours. J Pathol. 1997;183(2):131-133.

4. Motzer RJ, Bander NH, Nanus DM, Renal-cell carcinoma. $N$ Engl J Med. 1996;335(12):865-875.

5. Motzer RJ, Hutson TE, Tomczak P, et al. Sunitinib versus interferon alfa in metastatic renal-cell carcinoma. $N$ Engl J Med. 2007;356(2): $115-124$.

6. Escudier B, Eisen T, Stadler WM, et al. Sorafenib in advanced clear-cell renal-cell carcinoma. $N$ Engl J Med. 2007;356(2):125-134.

7. Motzer RJ, Escudier B, Oudard S, et al. Efficacy of everolimus in advanced renal cell carcinoma: a double-blind, randomised, placebocontrolled phase III trial. Lancet. 2008;372(9637):449-456.

8. Hudes G, Carducci M, Tomczak P, et al. Temsirolimus, interferon alfa, or both for advanced renal-cell carcinoma. NEngl J Med. 2007;356(22): 2271-2281.

9. Escudier B, Pluzanska A, Koralewski P, et al. Bevacizumab plus interferon alfa-2a for treatment of metastatic renal cell carcinoma: a randomised, double-blind phase III trial. Lancet. 2007;370(9605):2103-2111.

10. Sternberg CN, Davis ID, Mardiak J, et al. Pazopanib in locally advanced or metastic renal cell carcinoma: results of a randomised phase III trial. J Clin Oncol. 2010;28(8):1061-1068.

11. Rini BI, Escudier B, Tomczak P, et al. Comparative effectiveness of axitinib versus sorafenib in advanced renal cell carcinoma (AXIS): a randomised phase 3 trial. Lancet. 2011;378(9807):1931-1939.

12. Ferlay J, Parkin DM, Steliarova-Foucher E. Estimates of cancer incidence and mortality in Europe in 2008. Eur J Cancer. 2010;46(4):765-781.

13. Siegel R, Naishadham D, Jemal A. Cancer statistics. CA Cancer J Clin. 2012;62(1):10-29.

14. Seer.cancer.gov. Cancer of the kidney and renal pelvis - SEER stat fact sheets. Available from: http://seer.cancer.gov/statfacts/html/kidrp.html Accessed March 6, 2013.

15. Lam JS, Leppert JT, Belldegrun AS, Figlin RA. Novel approaches in the therapy of metastatic renal cell carcinoma. World $J$ Urol. 2005;23(3):202-212.

16. Motzer RJ, Bander NH, Nanus DM. Renal-cell carcinoma. $N$ Engl $J$ Med. 1996;335(12):865-875.

17. Janzen NK, Kim HL, Figlin RA, Belldegrun AS. Surveillance after radical or partial nephrectomy for localized renal cell carcinoma and management of recurrent disease. Urol Clin North Am. 2003;30(4):843-852.

18. Yancik R, Ganz PA, Varricchio CG, Conley B. Perspectives on comorbidity and cancer in older patients: approaches to expand the knowledge base. J Clin Oncol. 2001;19(4):1147-1151.

19. Kirkali Z. Kidney cancer in the elderly. Urol Oncol. 2009;27(6): 673-676.

20. Charlson ME, Pompei P, Ales KL, MacKenzie CR. A new method of classifying prognostic comorbidity in longitudinal studies: development and validation. $J$ Chronic Dis. 1987;40(5):373-383.

21. Hall JC, Hall JL. ASA status and age predict adverse events after abdominal surgery. J Qual Clin Pract. 1996;16:103-108.

22. Wieland D, Hirth V. Comprehensive geriatric assessment. Cancer Control. 2003;10:454-462.

23. Balducci L, Extermann M. Management of the frail person with advanced cancer. Critical Rev Oncol Hematol. 2000;33(2):143-148.

24. Lee SJ, Lindquist K, Segal MR, Covinsky KE. Development and validation of a prognostic index for 4-year mortality in older adults. JAMA. 2006;295(7):801-808.
25. Carey EC, Walter LC, Lindquist K, Covinsky KE. Development and validation of a functional morbidity index to predict mortality in communitydwelling elders. J Gen Intern Med. 2004;19(10):1027-1033.

26. Sun M, Thuret R, Abdollah F, et al. Age-adjusted incidence, mortality, and survival rates of stage-specific renal cell carcinoma in North America: a trend analysis. Eur Urol. 2011;59(1):135-141.

27. Frank I, Blute ML, Cheville JC, Lohse CM, Weaver AL, Zincke H. Solid renal tumors: an analysis of pathological features related to tumor size. J Urol. 2003;170(6 Pt 1):2217-2220.

28. Volpe A, Mattar K, Finelli A, Kachura JR, Evans AJ, Geddie WR, et al. Contemporary results of percutaneous biopsy of 100 small renal masses: a single center experience. J Urol. 2008;180(6):2333-2337.

29. Volpe A, Kachura JR, Geddie WR, Evans AJ, Gharajeh A, Saravanan A, et al. Techniques, safety and accuracy of sampling of renal tumors by fine needle aspiration and core biopsy. J Urol. 2007;178(2):379-386.

30. Escudier B, Eisen T, Porta C, et al. Renal cell carcinoma: ESMO clinical practice guidelines for diagnosis, treatment and follow-up. Ann Oncol. 2012;23(Suppl 7):65-71.

31. Volpe A, Cadeddu JA, Cestari A, et al. Contemporary management of small renal masses. Eur Urol. 2011;60(3):501-515.

32. Al-Qudah HS, Rodriguez AR, Sexton WJ. Laparoscopic management of kidney cancer: updated review. Cancer Control. 2007;14(3): 218-230.

33. Portis AJ, Yan Y, Landman J, et al. Long-term followup after laparoscopic radical nephrectomy. J Urol. 2002;167(3):1257-1262.

34. Guzzo TJ, Allaf ME, Pierorazio PM, et al. Perioperative outcomes of elderly patients undergoing laparoscopic renal procedures. Urology. 2009;73(3):572-576.

35. Frank I, Blute ML, Leibovich BC, Cheville JC, Lohse CM, Zincke H. Independent validation of the 2002 American Joint Committee on Cancer primary tumor classification for renal cell carcinoma using a large, single institution cohort. J Urol. 2005;173(6):1889-1892.

36. Go AS, Chertow GM, Fan D, McCulloch CE, Hsu C. Chronic kidney disease and the risks of death, cardiovascular events, and hospitalization. N Engl J Med. 2004;351(13):1296-1305.

37. Van Poppel H, Da Pozzo L, Albrecht W, et al. A prospective, randomised EORTC intergroup phase 3 study comparing the oncologic outcome of elective nephron-sparing surgery and radical nephrectomy for low-stage renal cell carcinoma. Eur Urol. 2011;59(4):543-552.

38. Patard J-J, Shvarts O, Lam JS, et al. Safety and efficacy of partial nephrectomy for all $\mathrm{T} 1$ tumors based on an international multicenter experience. $J$ Urol. 2004;171(6 Pt 1):2181-2185, quiz 2435.

39. Simmons MN, Weight CJ, Gill IS. Laparoscopic radical versus partial nephrectomy for tumors $>4 \mathrm{~cm}$ : intermediate-term oncologic and functional outcomes. Urology. 2009;73(5):1077-1082.

40. Van Poppel H, Da Pozzo L, Albrecht W, et al. A prospective randomized EORTC intergroup phase 3 study comparing the complications of elective nephron-sparing surgery and radical nephrectomy for low-stage renal cell carcinoma. Eur Urol. 2007;51(6):1606-1615.

41. Lau WK, Blute ML, Weaver AL, Torres VE, Zincke H. Matched comparison of radical nephrectomy vs nephron sparing surgery in patients with unilateral renal cell carcinoma and a normal contralateral kidney. Mayo Clin Proc. 2000;75:1236-1242.

42. La Rochelle J, Shuch B, Riggs S, et al. Functional and oncological outcomes of partial nephrectomy of solitary kidneys. J Urol. 2009;181(5): 2037-2042.

43. Lesage K, Joniau S, Fransis K, Van Poppel H. Comparison between open partial and radical nephrectomy for renal tumours: perioperative outcome and health-related quality of life. Eur Urol. 2007;51(3):614-620.

44. Hellenthal NJ, Mansour AM, Hayn MH, Schwaab T. Renal cell carcinoma in octogenarians: nephron sparing surgery should remain the standard of care. J Urol. 2011;185(2):415-420.

45. Berdjis N, Hakenberg OW, Novotny V, Froehner M, Wirth MP. Treating renal cell cancer in the elderly. BJU Int. 2006;97(4):703-705.

46. Staehler M, Haseke N, Stadler T, et al. Renal surgery in the elderly: morbidity in patients aged $>75$ years in a contemporary series. $B J U$ Int. 2008;102(6):684-687. 
47. Roos FC, Pahernik S, Melchior SW, Thüroff JW. Renal tumour surgery in elderly patients. BJU Int. 2008;102(6):680-683.

48. Kunkle DA, Uzzo RG. Cryoablation or radiofrequency ablation of the small renal mass: a meta-analysis. Cancer. 2008;113(10):2671-2680.

49. Carrafiello G, Laganà $D$, Ianniello $A$, et al. Percutaneous radiofrequency thermal ablation of renal cell carcinoma: is it possible a day-hospital treatment? Int J Surg. 2008;6(Supp1 1):s31-s35.

50. Tracy CR, Raman JD, Donnally C, Trimmer CK, Cadeddu JA. Durable oncologic outcomes after radiofrequency ablation: experience from treating 243 small renal masses over 7.5 years. Cancer. 2010;116(13): $3135-3142$.

51. Choueiri TK, Schutz FAB, Hevelone ND, et al. Thermal ablation vs surgery for localized kidney cancer: a Surveillance, Epidemiology, and End Results (SEER) database analysis. Urology. 2011;78(1):93-98.

52. Klatte T, Grubmüller B, Waldert M, Weibl P, Remzi M. Laparoscopic cryoablation versus partial nephrectomy for the treatment of small renal masses: systematic review and cumulative analysis of observational studies. Eur Urol. 2011;60(3):435-443.

53. Cornelis F, Balageas P, Le Bras Y, et al. Radiologically-guided thermal ablation of renal tumours. Diagn Interv Imaging. 2012;93(4): 246-261.

54. Schmit GD, Thompson RH, Kurup AN, et al. Percutaneous cryoablation of solitary sporadic renal cell carcinomas. BJU Int. 2013;189(1):30-35.

55. Bosniak MA, Birnbaum BA, Krinsky GA, Waisman J. Small renal parenchymal neoplasms: further observations on growth. Radiology. 1995;197(3):589-597.

56. Abou Youssif T, Kassouf W, Steinberg J, Aprikian AG, Laplante MP, Tanguay S. Active surveillance for selected patients with renal masses: updated results with long-term follow-up. Cancer. 2007;110(5): $1010-1014$

57. Chawla SN, Crispen PL, Hanlon AL, Greenberg RE, Chen DYT, Uzzo RG. The natural history of observed enhancing renal masses: meta-analysis and review of the world literature. J Urol. 2006;175(2): 425-431.

58. Laguna MP, Kümmerlin I, Rioja J, de la Rosette JJ. Biopsy of a renal mass: where are we now? Curr Opin Urol. 2009;19(5):447-453.

59. Beisland C, Hjelle KM, Reisaeter LAR, Bostad L. Observation should be considered as an alternative in management of renal masses in older and comorbid patients. Eur Urol. 2009;55(6):1419-1427.

60. Lane BR, Abaouassaly R, Gao T, et al. Active treatment of localized renal tumors may not impact overall survival in patients aged 75 years or older. Cancer. 2010;116(13):3119-3126.
61. Negrier S, Escudier B, Lasset C, et al. Recombinant human interleukin-2, recombinant human interferon alfa-2a, or both in metastatic renal-cell carcinoma. N Engl J Med. 1998;338(18):1272-1278.

62. Coeberg JW, Janssen-Heijnen ML, Post PN, Razenberg PP. Serious co-morbidity among unselected cancer patients newly diagnosed in the southeastern part of The Netherlands in 1993-1996. J Clin Epidemiol. 1999;52(12):1131-1136.

63. Bellmunt J, Négrier S, Escudier B, Awada A, Aapro M; SIOG Taskforce. The medical treatment of metastatic renal cell cancer in the elderly: position paper of a SIOG taskforce. Crit Rev Oncol Hematol. 2009;69(1):64-72.

64. Huston TE, Bukowski RM, Rini BI, et al. A pooled analysis of the efficacy and safety of sunitinib in elderly patients with metastatic renal cell carcinoma. J Clin Oncol. 2011;29 Suppl:s4604.

65. de Giogi U, Rihawi K, Lo Re G, et al. Sunitinib as first-line therapy in elderly patients (age 70 and older) with metastatic renal cell cancer. J Clin Oncol. 2012;30(Supp1 5):s411.

66. Motzer RJ, Michaelson MD, Redman BG, et al. Activity of SU11248, a multitargeted inhibitor of vascular endothelial growth factor receptor and platelet-derived growth factor receptor, in patients with metastatic renal cell carcinoma. J Clin Oncol. 2006;24(1):16-24.

67. Eisen T, Oudard S, Szczylik C, et al. Sorafenib for older patients with renal cell carcinoma: subset analysis from a randomized trial. $J$ Natl Cancer Inst. 2008;100(20):1454-1463.

68. Melichar B, Koralewski P, Ravaud A, et al. First line bevacizumab combined with reduced dose interferon alpha-2a is active in patients with metastatic renal cell carcinoma. Ann Oncol. 2008;19:1470-1476.

69. Dutcher JP, Tannir N, Bellmunt J, Escudier B. Experience with sorafenib and the elderly patient. Med Oncol. 2010;27(4):1359-1370.

70. Escudier B, Porta C, Bono P, et al. Patient preference between pazopanib and sunitinib: results of a randomized double-blind, placebo-controlled, cross-over study in patients with metastatic renal cell carcinoma (mRCC)-PISCES study, NCT01064310. J Clin Oncol. 2012;30(Suppl):CRA4502.

71. Motzer B, Hutson TE, Reeves J, et al. Randomized, open-label, phase III trial of pazopanib versus sunitinib in first-line treatment of patients with metastatic renal cell carcinoma: results of the COMPARZ trial. European Society for Medical Oncology Conference. 2012 Sep 28-Oct 2; Vienna, Austria.
Clinical Interventions in Aging

\section{Publish your work in this journal}

Clinical Interventions in Aging is an international, peer-reviewed journal focusing on evidence-based reports on the value or lack thereof of treatments intended to prevent or delay the onset of maladaptive correlates of aging in human beings. This journal is indexed on PubMed Central, MedLine, the American Chemical Society's 'Chemical Abstracts

\section{Dovepress}

Service' (CAS), Scopus and the Elsevier Bibliographic databases. The manuscript management system is completely online and includes a very quick and fair peer-review system, which is all easy to use. Visit http://www.dovepress.com/testimonials.php to read real quotes from published authors. 